\title{
Historical Narration and Literary Imagination: The Chinese Poems of the Angel Island
}

\author{
Yu-Ju Hung \\ History Department, Chinese Culture University, Taiwan \\ Email: HYR11@ulive.pccu.edu.tw
}

Received 28 Septemer 2015; accepted 24 December 2015; published 29 December 2015

Copyright @ 2015 by author and Scientific Research Publishing Inc.

This work is licensed under the Creative Commons Attribution International License (CC BY).

http://creativecommons.org/licenses/by/4.0/

(c) (i) Open Access

\begin{abstract}
The debate about the essence of historical narration between investigation of empirical sources and the historical imagination in line with literature genre and poetic act usually challenges classic definition of history and historical methodology. Modified theories try to connect the narrative forms of creative literature and the literary imagination to conventional historical writing, as well as by rethinking the boundary of text and context. In this article, the examination of Angel Island poems in many ways demonstrates varied applications for the historical narrations and provides critical historical resources through multiple representations of historical imaginations with cross-time and cross-space figurativeness and metaphors.
\end{abstract}

\section{Keywords}

\section{Angel Island Poetry, Chinese Immigration, Historical Imagination, Anti-Chinese Movement}

\section{Introduction}

The traditional historical writing and concept usually try to define the history along the precise lines of academic departments, limited specialization, and disciplinary boundaries ${ }^{1}$ (Gossman, 1990). However, modified criticism in the later part of the twentieth century increasingly suggests a blurring boundary between traditional historical narration and literature, represented by Hayden White's works. These scholars argue that history can never be entirely separated from literature or philosophy or other disciplinary languages, though it can never be identical

\footnotetext{
${ }^{1}$ In prior to eighteenth century, history was a subject subordinating to literature. It was in the late eighteenth century that scientific history, proposed by German historian Leopold von Ranke, started to be distinguished as specific academic discipline, with focus on empiricism (using primary sources, employing archival research and exercising analysis of historical documents), from literature.
} 
to those other discourse, either ${ }^{2}$ (White, 1973; Gallie, 1964; Danto, 1965, 1985; Kramer, 1989). In so doing, the relationship between historiography and literature can be diversified and complex, giving birth of ideas that historical narration is supposed to go beyond conventional structure in the context of scientific and objective examinations of primary materials and non-emotional narrative pattern.

For decades, this kind of arguments earns evaluations from pros and cons in a multitude of academic and popular works. Historians fervently debate about the essence of historical narration between investigation of empirical sources and the product of the subjectively historical imagination and creation as discovery in the archive. This essay does not focus on the dispute or compatibility concerning scientific historical narration and fictive reconstruction of historical imagination based on inevitably historians' subjective rearrangement of materials. Rather, it employs a special historical collection, the Chinese poems in the Angel Island, to provide additional discourse about historical imagination, fictive narration, and metaphor indication, showing how alternative historical narrative is able to be naturally demonstrated in an unorderly but traceable form in conjunction with ethnically minority experiences in the United States.

\section{Angel Island in the Context of Chinese American History}

The formation of Angel Island literature is broadly placed in the context of anti-Chinese and anti-immigration since the mid- $19^{\text {th }}$ century. From 1849, Gold Fever in California opened the door for importing the Chinese to fulfill the demand of human forces in many local mines. In 1850s, over 41,000 Chinese workers were permitted to enter the United States, in California solely inhabited by 34,933 Chinese. In the following twenty years, the construction of transcontinental railroads and the development in the towns of western frontier continued to lure more Chinese newcomers. In 1880, the Chinese population in the United States culminated to over ten hundred thousands, with nearly 75,000 in California ${ }^{3}$ (Sandmeyer, 1991). These Chinese immigrants appeared throughout expansive territories in the West, ranging from Nevada, Colorado, Arizona to Oregon. They contributed considerably to local advancement in industries of mining, agriculture and manufacture ${ }^{4}$ (Bancroft, 1886; Takaki, 1993; Aarim-Heriot, 2003; Kwong, 2005). As Arif Dirlik claimed, Chinese immigrants are one of the most significant pioneers and contributors to the development of Western Frontiers in the nineteenth century (Related discussion includes Dirlik, 2003; Lawton, 1970; Riverside Municipal Museum, 1991; Great Basin Foundation edited, 1987; Wong, 2004; Chung, 2011; Zhu, 1997).

However, Sinophobia arose with the increaseof Chinese workers in the United States. This anti-Chinese sentiment initiated among working-class group, first motivated by the Knights of Labor and the Workingmen's Party against "Chinese coolie," whom they blamed for the scapegoat of their plight of lower wage and rising unemployment $^{5}$ (Kwong, 2005; Eaves, 1910; Staff writer, 1878). In the middle of 1870s, the anti-coolie activities rapidly mounted from labor-oriented to fight against the whole Chinese immigration group. Chinese was thus perceived as "sojourners", with the alienable characteristics, measured by their different skin color, appearances, language, and culture, unassimilable to the mainstream society. Many contemporary documents in the nineteenth century even marked Chinese males as the natural thieves, and Chinese females as prostitutes.

\footnotetext{
${ }^{2}$ Hayden White, W.B. Gallie, Arthur Danto all claim that history and literature is not clear-cut. Rather, As White advises, historical narration inherently contains literature genre and fictive elements.

${ }^{3}$ According to U.S. census, 64,301 Chinese were permitted to enter to the United States in 1860s; 122,201 in 1870s. See U.S. Census of 1880 .

${ }^{4}$ American government played significant role in encouraging the importation of Chinese labors in 1850s and 1860s. As early as 1848, Aaron Palmer, a counselor of the Supreme Court of the United States, forecasted that San Francisco would be the "great emporium of our commerce on the Pacific", so that he suggested that Chinese workers be imported to fill the labor market in the West. In 1852, Californian Governor John McDougal praised Chinese laborers as “one of the most worthy classes of our newly adopted citizen”, and proposed a plan to import Chinese to replace the black and Mexican workers in the West Frontier; In 1852, Senator (George B. Tingley) also provided a unpassed draft, indicating the importance to use large number of cheap Chinese contracted laborers. This kind of official policies was proved critical for early booming of Chinese immigration in the 1850s and 1860s, when mines throughout the west coast, as well as the construction of the Central Pacific Railroad were eager for labor source. Nevertheless, the early policy to champion for the importation of Chinese workers mostly came out of the mind that Chinese were easier to be exploited with lower wages and longer daily hours, which many American workers were not able to afford.

${ }^{5}$ The Knights of Labor was established in 1869 as the representative organization against Chinese workers. Its publication, Journal of United Labor, usually targeted Chinese as the main reason for the plight of white laborers. In 1870, Knights of Labor worked together with other local trade unions in San Francisco and Los Angeles to conduct anti-Chinese boycotts and demonstrations. These labor unions included the Knights of St. Crispin, Plumbers’, Carpenters’ Eight Hour League, and Anti-Coolie Union of San Francisco. Its leader, Dennis Kearney, promoted firmly anti-Chinese activities in local and national levels, leading to the passage of discriminatory California Constitution of 1879 , and later the Chinese Exclusion Act in 1882.
} 
This narrow-views and discriminatory remarks against Chinese authorized anti-Chinese movement (Kwong, 2005).

In early 1870s, encouraged by the worker union, anti-Chinese sentiment started to influence the official policies and legislations. In 1870, two laws were passed by Californian Legislature to empower local police to monitor Chinese (Asian) criminals, slaves, and illegal immigrants, as well as susceptible prostitution ${ }^{6}$ (Aarim-Heriot, 2003). Similarly, in 1870, the California Statutes were added with the words that all Chinese men were "inveterate coolie”, all Chinese women were "degenerate prostitutes”, which later be used by Congressman Horace F. Page in a resolution in 1875 that aimed to prohibit importation of Chinese women "for immoral purposes". The Page Act, named after its bill proposer Horace Page, also devoted to prohibit importation of Chinese "coolie"; although it showed no practical impact on Chinese male immigration, it certainly proved an effective measure in limiting the entry of Chinese women ${ }^{7}$ (Hom, 1987; Kwong, 2005).

There were municipal regulations against Chinese in certain cities, particularly in San Francisco, the center of Chinese American immigration in nineteenth century. In 1870, lodge housing ordinance (or cubic air ordinance) was passed to ask that the living space for every city resident should at least reach to 500 cubic feet. Those who disobeyed this ordinance would be penalized with fees from 10 to 500 dollars, and imprisonment from five days to three months at most. This ordinance apparently targeted local Chinatown, where growing Chinese population squeezed in dense small area (Yang, 2009). In 1873, San Francisco’s Board of Supervisors passed Pagan Orders to harshly supervise local Chinese laundry industry (Aarim-Heriot, 2003; Sandmeyer, 1991). In 1880, another San Francisco's municipal code also attempted to outlaw the Chinese laundry with wooden equipment, which as government claimed, easily caused fire (Lee, 2002).

In the aftermath of 1875, national economic depression increasingly promoted the anti-Chinese sentiment. As worker's unions threatened to ask Congress by their votes, both Democratic and Republican Parties came to agreement on the policy to limit Chinese immigration. A congressional committee made up by representatives of both parties in 1876 provided a report to underscore the essence of Chinese immigrants as "indigestible mass in the community" suggesting that Chinese not only unqualified to own voting rights but also deserved the situation to be segregated. This strong wave of anti-Chinese activities further fostered their efforts, particularly encouraged by Workers' Party, on the restriction of incessant Chinese immigration in the legislative aspect. The passage of California Constitution of 1879, along with the draft of Bill to Enforce Treaty Stipulations relating to the Chinese proposed by Californian Senator John F. Miller in 1881, both revealed anti-Chinese movements in the political arena nationally ${ }^{8}$ (Fong \& Markham, 2002). More often than not, the draft in 1881, after fervent discussion in the two Houses, became the basis to create the notorious Chinese Exclusion Act of 1882 (Fong \& Markham, 2002).

The passage and enforcement of the Chinese Exclusion Act of 1882 both signaled Chinese as the first ethnic group being forbidden to immigrate to the United States, as well as became the watershed to mark transformation of American immigration policy, from early stage of open and free immigration to the creation of quota system, aiming to select amiable ethnic groups recognized by Americans as benevolent to the host society. It was proved by a series of legislation in the aftermath of 1882 that further restricted Chinese (Asian) citizenship. In 1888, the enactment of Scott Act prohibited Chinese rights who returned to China to reenter the country legally, affecting more than twenty thousand Chinese who were traveling between the two sides of Pacific Ocean when the act was effective; The passage of the Geary Act of 1892 not only extended the Chinese Exclusion Act of 1882 for another ten years, but also required the Chinese staying in the United States to carry a certificate of residence. Those without the certificate were destined to deport or imprison for a year of hard labor. This anti-Chinese lobby activities in public politics continued till early twentieth century when another ten-year prolonging renewal of Chinese Exclusion Act took place in 1901, one year before the Geary Act was about to expire. The immigration Act of 1907 further imposed restrictions upon Chinese insufficient of English ability to enter the country, while enacted stricter examination for Chinese who had stayed in the United States to apply for the permanent residence (Courtney, 1956; Lee, 2002; Daniels, 1988). The legislative limitation stemming since 1870s terminated the flow of Chinese American immigration until 1942.

In addition to legal restriction upon Chinese immigrants, violent activities against Chinese also increased ra-

\footnotetext{
${ }^{6}$ The two laws: An Act to Prevent the Importation of Chinese Criminals, and to Prevent the Establishment of Chinese Slavery; An Act to Preventing the Kidnapping and Importation of Mongolian, Chinese and Japanese Females, for Criminal and Demoralization Purposes.

${ }^{7}$ From 1876 to 1882, every Chinese woman traveling to U.S. should be interviewed by officials: first in Hong Kong, by British colonial officials, and then be questioned by U.S. Port Authority when she arrived at the point of disembarkment.

${ }^{8}$ See California Constitution (1879), article 2, Section 1; California Constitution (1879), article19, Section 1, Section 2, Section 3, and Section 4.
} 
pidly in the post-era of Chinese Exclusion Act. The frequency that Chinese encountered mounting hostile treatments was probably attributed to their residential transformation to the city ethnic enclaves in the aftermath of 1870s, when Chinese laborers started to lose working opportunities in the rural mines and farms. These Chinese gradually concentrated in cities developed specific ethnic businesses, characterized by the booming Chinese restaurants, grocery stores, and laundries. It forced Chinese more interacting with mainstream society, alluring growingly unfriendly doubt for their presence. Hence, since 1880s, almost every Chinatown in the West, including San Francisco, Los Angeles, Inland Empire, and smaller towns in Washington state, Arizona, and Wyoming all encountered accidents of robbery, felony and arson (Thompson, 1978; Lawton, 1987; Karlin, 1954; Sowell, 1981). Moreover, official hygiene laws and disease inspection clouded the residents in Chinatown after 1890s, resulting frequent Chinese re-migration in the following years. Most Chinese Americans chose residential self-segregation, while many decided to return to their homeland in China in the first half of the twentieth century. In this complicated historical context, Angel Island was built in the early twentieth century principally to aid federal agencies to enforce strict racial restrictions on the Chinese and Asian immigration. The Angel Island Immigration Station thus became the primary center as the United States' government evolved "Asianbarred zone" policy, which was enforced with similar idea to inspect European immigrants, particularly those from Eastern and Southern Europe, in the Ellis Island, located near New York harbor. However, for many immigrants, particularly those from China, the experience at Angel Island commonly disappointed and intolerable. For decades after the ban of Chinese Exclusion Act of 1882 on the entry of Chinese laborers, limited accesses were left for Chinese immigrants to apply for the permission to enter United States. Only few entered this country as American-born sons and daughters of Chinese immigrants. After the 1906 San Francisco earthquake destroyed many essential records, more Chinese surprisingly sought to enter, many claiming fictitious family ties, as status of paper sons or daughters of Chinese American citizens. The Angel Island Immigration Station arose from the government's desire to detain immigrants, most often Chinese, during the lengthy interrogation process that would determine their admissibility.

Therefore, the detainment of a large number of Chinese in Angel Island Immigration Station, mostly be detained from a couple months to three years at most, not only continues to reflect anti-Chinese spirit in the host society, but also expresses collective and substantial records, through hundreds of poems inscribed by Chinese immigrants on the wall of the rooms in the Station. These Chinese poems symbolize valuable historical writings, combined with common feelings of anxiety, anger, shame, and helplessness dented by imaginative, fictive, and unorderly words. These personal and collective records by poetry demonstrate a unique historical narration form to increase our understanding both about Chinese experiences in the context of anti-Chinese sentiment, while to add valuable example of literary text for the narrative forms.

\section{Convergence of Historical Narration and Imagination}

In his masterpiece, Metahistory, Hayden White challenges conventional wisdom to claim that narrative historiography embodies with essence to "dramatize historical and novelize historical processes". He argues that if historical narration can "inherently be developed, and formally has the most coherent representations in the literary or poetic endowment of secularized culture, no reason to rule them out as merely imaginary constructions” (White, 1973). In this vein, White strongly articulates a nature-embedded essence of literature genre or essentially poetic act within any type of historical narratives. As a result, "the denial that literature and poetry have anything valid to teach us about reality”, as White suggests, is a doubtful conception. Here, White stresses the significance of literature and poetic genre that conventional historians avoid to conduct in their narratives (White, 1973).

Nevertheless, the idea of poetic act or linguistic tropes that White and other scholars propose is more complicated than it literally implies. It both demonstrates the mixture of imaginative and creative core that any historical narratives embody, while further thoughts about alternative forms of historical narration are also been firmly suggested. Linda Orr's "the Revenge of Literature", echoes the view that the literature, including poetry, not only describes the reexamination of inseparable relationship between the historical imagination, the historical discourse and past lived experience, but also shows flexible and unlimited narrative genres that historical materials self-possess (Orr, 1987). It affirms the voices in academic fields in recent years that history can be read and written by multi-facet and diversified patterns.

The thoughts that Hayden White and other scholars claim genuinely expand the classic definitions of history 
and historical methodology by connecting the narrative forms of creative literature and the literary imagination to conventional historical writing, as well as by rethinking the boundary of text and context. They address that literature, equipped with internal meaning order, can serve as the alternative form of historical narration and be regarded as sources of text. Such assertions point to a potential avenue and methodology for researches on the history of Chinese Americans by taking the early Chinese American literature, poems, fictions, and novels into consideration (Paul, 2011).

In the light of abovementioned notion about non-traditional historical narration, the Chinese poetry in Angel Island provides unique thoughts to testify these theories in different aspects. Accordingly, Angel Island poems, which were inscribed by early Chinese immigrants on the walls of the barracks at Angel Island between 1910 and 1940, can be reexamined not only in the fields of literature and art, ${ }^{9}$ but also as a form of narrative revealing the experiences and thoughts of early Chinese in their specifically historical context.

Hayden White, in his another masterpiece, The Content of the Form: Narrative Discourse and Historical Representation, identifies the historical narratives with the authority related to the subjective judgment of morality (White, 1987). Dominick LaCapra, in the introduction article for the book, The Bounds of Race: Perspectives on Hegemony and Resistance, urges us to allow the particular ethnic group speaking from its position rather than directly applying the dominant academic perspectives toward them as well (Kramer, 1989). Both scholars suggest having a close look at previously marginalized ethnic texts, sources, and literature. Resonating what they claim, the researches and translations toward Angel Island poems initiated in the 1980s by Chinese scholars such as Him Mark Lai, Judy Yung, and Genny Lim all held the position that attempted to allow the silent Chinese to voice the grievous situations which specific ethnic immigrants encountered. Hence, through the recovery of Angel Island poems, the early Chinese immigrants in the detention center exhibited the vivid discourses with outspoken moral assertions toward the U.S. Government, which they considered as the origin of oppression they suffered. In this light, the Angel Island poems function in some ways to balance or even counter the conventional views of American society toward the Chinese and create the advantageous moral and ethnic space for themselves.

Moreover, as what LaCapra claims that historians should examine the literature in its historical context, scholars such as Peter Kvidera, Cynthia F. Wong, Robert Barde and Gustavo J. Bobonis each analyze the Angel Island poems in their particular historical context (Wong, 1999; Kvidera, 2005; La Ganga, 2009; Barde \& Bobonis, 2006). Essentially, poetry could not be created without being in harmony with its historical context. To examine the contemporary Chinese immigrants, one also needs to consider the contemporary environment of China, other than just anti-immigration context in the contemporary United States, in the early twentieth century, when China experienced shift transformations from Qing Dynasty to Republic of China coupled with decades of incessant divisions of many military forces that kept China in the humiliated state of a sub-colony until World War II. Thus, the creation of Angel Island poetry, to a certain degree, also presents the zeitgeist through its representation of the collective sense of complex-fear, anxiety, hopelessness, helplessness, self-pity, self-complaints, humiliation, anger, and hope among immigrants, which were influenced significantly by the environments of both China and the United States. These traits can be found in related studies on Angel Island poetry. For instance, Kvidera discusses the poems in the context of Chinese Exclusion Act and subsequent restrictive laws toward the Chinese in America. He studies the connection between the legal narratives and literary space in the poetry. In short, he demonstrates that through poems Chinese immigrants turned a legally inscribed absence into a literary presence, and the aesthetic that the Angel Island writers developed allows them to imagine a Chinese position in the United States which ideally defied legal definitions remaining otherwise beyond their control (Kvidera, 2005). Cynthia F. Wong analyzes the attributes of anonymity and self-laceration in the poems to express the emotional anguish of the authors' exilic state, their helplessness while demonstrating their self-reliance and dignity; Robert Barde and Gustavo J. Bobonis’s work concentrate on the empirical evidence-data on passengers of the Pacific Mail Steamship Company (PMSS) during the period 1913-1919. Through statistical analysis, their work reflect some slight details different from previous awareness of the detainees on Angel Island, roughly confirming the constant miserable situations that Chinese immigrants faced while in the detention center.

\footnotetext{
${ }^{9}$ The famous American literature scholar Paul Lauter selected thirteen pieces poems into his significant work-The Heath Anthology of American Literature, a collection that includes more than five thousand pieces of American literary works. It reveals that the Angel Island poems are valued by mainstream academic field as representation of the early Chinese American literature.
} 
In addition to considering Angel Island poems in the domain of specific historical context, these poems themselves also embody interesting meanings to present special historical literary form, as abovementioned. In general, poetry as a form of historical record is quite common in Chinese traditions. In Chinese history, especially during the Tang Dynasty period, which spanned from 618 to 907, A.D., poetry is perceived as one of the prevalent narrative forms. Poems not only constitute one part of the Governmental exams for selecting officials, but serve as the most important literary style among the intellectuals of the period and afterwards. The 300 Tang Poems, the most famous anthology of Chinese poems, influence the Chinese immensely. Until the early twentieth century, it is still so common for the Chinese to express their feelings, emotions, and thoughts through poetry.

The Angel Island poems mark the fact that poetry remains as one of the important narrative pattern for early Chinese Americans. As Hayden White and Dominick LaCapra suggest, to a certain extent, Angel Island poetry can be treated as the reflection of contemporary Chinese live experiences in the United States, even the poems are not so well-structured and the subjects of poems are sometimes aimless. Nevertheless, through the compilation of Chinese historians, led by Him Mark Lai, the collection, Island: Poetry and History of Chinese Immigrants on Angel Island, 1910-1940, shows chronical and organized contents with words full of emotions, imaginations, and metaphors (Lai and others, 1980; Hunt, 1989). This unique collection of Chinese poems witnesses what White's explanation of history as "the act of imposing a narrative or emplotment of a particular kind on the past”, and knowledge of the past is sometimes “derived through an essentially poetic act” (Kramer, 1989).

As the essence of poetic collection, the Angel Island poems are invariably constructed with figurative and imaginative meanings; however, they also can be employed as one of the crucial historical resources and materials for early Chinese Americans by documentation and, as what White stresses, the "emplotment of the real events". Especially for Chinese, the frequent use of poetry as means of literary type sometimes empowers their poems combined with inherently narrative harmony and artistic flow of creation and imagination. It makes fugitive descriptions of their poems spotted with characteristics of historical chronicle and narrative structure (Kramer, 1989).

Resonating to the figurative, metaphorical and tropological applications of literature associated with the historical imaginations, Angel Island poems provide many interesting examples. For example, the phrase "laws harsh as tigers”, (\#10) is a famous Chinese proverb from Confucius which says, "oppressive rule is surely fiercer than any tiger” (Lai and others, 1980; Hunt, 1989). The "Flowery Flag” is a Cantonese colloquial term associated with a description of the U.S. Flag. "Gold Mountain” (\#36) is a term that the Chinese usually used for the United States or San Francisco. “Central Plains” (\#40) is often used by the Chinese to describe the lower Yellow River Valley, where the Chinese civilization has its beginning. The term "square-holed elder brother” (\#33) represents "money” because the ancient Chinese coin has a square hole in the center. Such figurative words and phrases within the poems diversify the narratives with aesthetic and historical imaginations.

Aside from these, the poems include many elements originated from Chinese famous figures, classical idioms, folks, legends, fables, as well as fairies. For example, "Su Wu”, the envoy of Han Dynasty (206 B.C.-24 A.D.) who was detained by a nomadic tribe for 19 years but never quit, and "Yu Xin," the envoy of Liang Dynasty (502-559 A.D.) who was detained by his enemies for years but kept his resistance as well, were often quoted by the authors of the poems to depict themselves, owing to the similar figurative situations of detention. The imaginative creatures such as "Jingwei bird”, which was transformed by the soul of a girl who drowned according to a Chinese legend, carried pebbles in her beak trying to fill the ocean (\#30,\#64), and "Peng”, a giant, mythical bird that reputedly could fly 10,000 "li”, approximately one third of a mile, (\#54) were also cited by the poems' authors to represent resoluteness and a promising future for themselves, respectively; "Youli”, (\#20) the place where the King Wen, founder of the Zhou Dynasty (1154-1122 B.C.), was captive from the previous Shang dynasty king, and "Yingtai Island”, an island located in the Nan Hai (Southern Lake), west of the Forbidden City in Peking, where the emperor Guangxu (1875-1908) was imprisoned by the Empress Dowager Cixi in 1898 after a coup d'etat to halt his reform programs, were often used by poets to compare the wooden building of Angel Island where they were detained. Besides, some poems possess metaphorical meaning hiding beneath the structure of the poetry. An example can be seen in one poem (\#46) (Lai and others, 1980; Hunt, 1989) in which the first character of each line of poem forms a sentence, "Island awaits leveling”, which hides the real expectation of the author. In addition, many Angel Island poems intentionally imitate the Chinese classical poems. For ex- 
ample, the "Inscription about a Wooden Building” (\#33) is one composition that imitates the classical work of "Inscription about a Humble House" (Loushi Ming), a famous poem in which the author attempted to express his comfortableness and aspiration in his humble situation. In sum, enormous applications of the Chinese elements for the figurative, metaphoric, and other literal meaning purposes effectively juxtapose the disparate space and time with imaginative accord in historical meanings, and enrich the abundance of the historical imaginations of the Angel Island poems.

Nevertheless, in certain aspects, the Angel Island poetry shows unavoidable weaknesses and problems upon its representation of historical discourse. First of all, what Angel Island poems presented was sort of the preimmigration experiences among the Chinese immigrants that entered into the America mainland. Therefore, what they thought about the American life, and expected for the future, no matter pursuing for fortune or otherwise, seemed based on the information from their fellows, trade brokers, and even groundless rumors. Besides, the fears resulting from their subterfuge immigration mean to America such as the "paper son", also reinforce their imaginations about the uncertainty of the future. One immigrant, Keng Wong, remembered that she and her family frantically studied their "coaching papers" that would allow them to pass the examinations of immigration interrogators to settle in the United States. "We lied to get in”, not only reflects the situation of Wong and her family, but also shows the collective mental status which most Chinese immigrants experienced (La Ganga, 2009). In this light, what they described in their poems seemed to present kinds of dual imaginations that combined the imaginations of Chinese immigrants' subjective but unreal expectations for their future lives in the United States with literal, and uncertain figurativeness. As a result, the Angel Island poetry only reveals partial experiences of early Chinese immigrants. To make up the deficiency, the Songs of Gold Mountain: Cantonese Rhymes From San Francisco Chinatown, which represents the real life experiences of early Chinese in America, coupled with the biographies and oral histories of Chinese of the contemporary, performs as the effective and reliable supplement of materials for the overall examination of the early Chinese in America (Lai and others, 1980).

Secondly, the abundance of figurativeness in Angel Island poems undoubtedly shows the fullness of historical imaginations. However, on the other hand, it inevitably merits the attention on how to examine the boundary of verity and imagination beneath the poems. Moreover, the figurative characteristic of the poems also possibly results in unavoidable ambiguity when judging the authors' real intentions. For instance, one poem (\#11) describes the author trying to seek rather than being Taogong, a wealthy merchant who lived during the 5th century and he always was regarded as the symbol of a successful merchant in the United States. From this sentence, it is hard to decide whether the author sought the support from specific rich people in America or just revealed his determination to be a rich man (Lai and others, 1980). Likewise, in another poem (\#45) the author mentioned that one-hundred-thousand men sharpened their swords preparing to behead the enemies. However, in conventional Chinese rhetoric, the phrase of "ten-hundred-thousand" invariably presents the meaning of immenseness or completeness rather than the calculation of numbers (Lai and others, 1980). Therefore, other explanation for this sentence can also be interpreted as that one man sharpens his sword seriously and completely to resist his enemies; the figurative meaning represents his determination to face the difficulty in his reality. In a word, the diverse employments of figurative words and phrases in the poems function as a two-edged sword with both assets and liabilities.

Thirdly, Angel Island poetry plays an important role in rebuilding the unnoticed facets of early Chinese immigrants in America from the perspective of Chinese who voiced their situations through poetry; thus, the poetry inevitably possesses strong sense of ethos and ethnic-identity. The common experiences of long and arduous voyage, together with the unfair treatments in the detention center, must further strengthen these early Chinese immigrants with sense of a brotherhood and comradeship. Obviously, such ethnicity and fellowship are easily expressed by the narrowly ethnic way, and even tend to be a fierce and ethnocentric rhetoric when the collective sense of plight emerges among the ethnic group. Hence, throughout Angel Island poems, it is easy to find that many poets were inclined to accuse or scold the officials and the doctors of the detention center, and even used toward the U.S. Government despiteful and xenophobic rhetoric. For example, with regard to Westerners, some

\footnotetext{
${ }^{10}$ In the book, Island: Poetry and History of Chinese Immigrants on Angel Island, 1910-1940, the scholars seemed to unify their translation to sole word- "barbarian” to cover several different Chinese words used in many poems with slight meaning difference. Actually, some Chinese words represented in the poems not only possess the meaning of barbarian, but with multiple indications of foreigner, uncivilized people, and slave.
} 
Chinese poets frequently used the words "barbarian"10 and "savage" to express their sentiments. Also, in one poem (\#41), the author vowed "never to stop till the white men are completely annihilated" while in another poem (\#43) the writer also vowed "to conquer the U.S. and avenge previous wrongs" (Lai and others, 1980). Although the views that the Chinese looked on Western world inescapably were influenced by traditional customs ${ }^{11}$ considering their depressed conditions, such rhetoric might purely vent their direct emotions other than be intentional attack over specific ethnic groups. Nevertheless, the inseparable bias, narrowness, and prejudice together with strongly subjective moral judgments existing in some poems bring about the problems about the proper way to appropriately examine and use the poems as historical narrations with comparatively detached attitudes.

\section{Conclusion}

In conclusion, the Angel Island poems in many ways demonstrate varied applications for the historical narrations and provide critical historical resources through multiple representations of historical imaginations with cross-time and cross-space figurativeness and metaphors. Also, Him Mark Lai and other editors roughly categorize Angel Island poems into five divisions - the voyage, the detainment, the weak shall conquer, about westerners, and deportees and transients. From such classification, the scholars attempt to express that the poetry is a dialogue which reflects the collective experiences within and beyond Chinese immigrants in their historical context. Although there are unavoidable weaknesses when adopting the methodology of White, LaCapra, and other scholars over Angel Island poetry as discussed in the above passages, the poetry is a great example of the advantages and value of including literature into the serious historical category.

\section{References}

Aarim-Heriot, N. (2003). Chinese Immigrants, African Immigrants, and Racial Anxieties in the United States, 1848-82. Urbana, IL: University of Illinois Press.

Bancroft, H. H. (1886). History of California VI, 1840-1860. San Francisco, CA: The History Company.

Barde, R., \& Bobonis, G. J. (2006). Detention at Angel Island: First Empirical Evidence. Social Science History, 30, 103136. http://dx.doi.org/10.1215/01455532-30-1-103

Chung, S. F. (2011). In Pursuit of Gold: Chinese American Miners and Merchants in the American West. Urbana, IL: University of Illinois Press.

Courtney, W. J. (1956). San Francisco's Anti-Chinese Ordinances, 1850-1900. Ph.D. Dissertation, San Francisco, CA: University of San Francisco.

Daniels, R. (1988). Asian America: Chinese and Japanese in the United States since 1850. Seattle, WA: University of Washington Press.

Danto, A. (1965). Analytical Philosophy of History. New York: Columbia University Press.

Danto, A. (1985). Narration and Knowledge. New York: Columbia University Press.

Dirlik, A. (Ed.) (2003). Chinese on the Frontier. Lanham, MD: Rowman \& Littlefield.

Eaves, L. (1910). A History of California Labor Legislation. Berkeley, CA: The University Press.

Fong, E. W., \& Markham, W. T. (2002). Anti-Chinese Politics in California in the 1870s: An Inter-County Analysis. Sociological Perspectives, 45, 183-210. http://dx.doi.org/10.1525/sop.2002.45.2.183

Gallie, W. B. (1964). Philosophy and the Historical Understanding. London: Chatto \& Windus.

Gossman, L. (1990). Between History and Literature. Cambridge, MA: Harvard University Press.

Great Basin Foundation Edited (1987). Wong Ho Leun: An American Chinatown (Volume One-History). San Diego, CA: The Great Basin Foundation.

Hom, M. K. (1987). Songs of Gold Mountain: Cantonese Rhymes from San Francisco Chinatown. Berkeley, CA: University of California Press.

Hunt, L. (Ed.) (1989). The New Cultural History. Berkeley, CA: University of California Press.

\footnotetext{
${ }^{11}$ For thousands of years, owing to the flourishing advancements in polity, economic, and culture, China generally posits herself in the center of the world, and gradually creates the notion of "Celestial Empire" that regards the countries or regions other than China as uncivilized, barbaric ones.
} 
Karlin, J. A. (1954). The Anti-Chinese Outbreak in Tacoma, 1885. The Pacific Historical Review, 23, 271-283. http://dx.doi.org/10.2307/3635568

Kramer, L. S. (1989). Literature, Criticism, and Historical Imagination: The Literary Challenge of Hayden White and Dominick LaCapra. In L. Hunt (Ed.), The New Cultural History (pp. 117-122). Berkeley, CA: University of California Press.

Kvidera, P. (2005). Resonant Presence-Legal Narratives and Literary Space in the Poetry of Early Chinese Immigrants. American Literature, 77, 511-539. http://dx.doi.org/10.1215/00029831-77-3-511

Kwong, P., \& Miscevic, D. (2005). Chinese America: The Untold Story of America's Oldest New Community. New York: The New Press.

La Ganga, M. L. (2009). Angel Island’s Ghostly Poems Tell of Exclusion. Los Angeles Times, February 13, 2009.

Lai, H. M., Lim, G., \& Yung, J. (1980). Island: Poetry and History of Chinese Immigrants on Angel Island, 1910-1940. San Francisco, CA: History of Chinese Detained on Island Project.

Lawton, H. W. (1970). Harry W. Lawton Collection on Riverside, California Chinatown, Special Collection Archives. Riverside, CA: Rivera Library of University of California.

Lawton, H. W. (1987). Denis Kearmey among the Orange Groves: The Beginning of the Anti-Chinese Movement in the Citrus Belt (1876-1880). In W. H. Leun (Ed.), An American Chinatown (Vol. 1, pp. 196-203). Riverside, CA: The Great Basin Foundation.

Lee, E. (2002). The Chinese Exclusion Example: Race, Immigration, and American Gatekeeping, 1882-1924. Journal of American Ethnic History, 21, 36-62.

Orr, L. (1987). The Revenge of Literature: A History of History. New Literary History, 18, 1-22. http://dx.doi.org/10.2307/468653

Paul, H. (2011). Hayden White: The Historical Imagination. Cambridge: Polity Press.

Riverside Municipal Museum (1991). Life in Little Gom-Benn: Chinese Immigrant Society in Riverside, 1885-1930. Riverside, CA: Riverside Municipal Museum.

Sandmeyer, E. C. (1991). The Anti-Chinese Movement in California. Urbana and Chicago, IL: University of Illinois Press.

Sowell, T. (1981). Ethnic America: A History. New York: Basic Books.

Staff Writer (1878). San Francisco Daily Evening Bulletin, January 10, 1878.

Takaki, R. (1993). A Different Mirror: A History of Multicutlural America. Boston, MA: Little, Brown.

Thompson, R. D. (1978). Founding of San Bernardino's Chinatown. Heritage Tales, 1, 4-10.

White, H. (1973). Metahistory: The Historical Imagination in Nineteenth-Century Europe. Baltimore, MD: Johns Hopkins University Press.

White, H. (1987). The Content of the Form: Narrative Discourse and Historical Representation. Baltimore, MD: John Hopkins University Press.

Wong, C. F. (1999). Anonymity and Self-Laceration in Early Twentieth Century Chinese Immigrant Writing. Melus, 24, 318. http://dx.doi.org/10.2307/468170

Wong, W. (2004). Oakland's Chinatown. Charleston, SC: Arcadia.

Yang, J. S. (2009). The Anti-Chinese Cubic Air Ordinance. American Journal of Public Health, 99, 440. http://dx.doi.org/10.2105/AJPH.2008.145813

Zhu, L. P. (1997). A Chinaman's Chance: The Chinese on the Rocky Mountain Mining Frontier. Boulder, CO: University Press of Colorado. 